\title{
Critical research needs for identifying future changes in Gulf coral reef ecosystems
}

\author{
David A. Feary a, ${ }^{a}$, John A. Burt ${ }^{b}$, Andrew G. Bauman ${ }^{c}$, Shaker Al Hazeem ${ }^{d}$, Mohamed A. \\ Abdel-Moati ${ }^{\mathrm{e}}$, Khalifa A. Al-Khalifa ${ }^{f}$, Donald M. Anderson ${ }^{\mathrm{g}}$, Carl Amos $^{\mathrm{h}}$, Andrew Baker ${ }^{\mathrm{i}}$, \\ Aaron Bartholomew', Rita Bento ${ }^{\mathrm{k}, \mathrm{l}}$, Geórgenes H. Cavalcante ${ }^{\mathrm{m}}$, Chaolun Allen Chen $^{\mathrm{n}}$, Steve \\ L. Coles ${ }^{o, p}$, Koosha Dabq, Ashley M. Fowler ${ }^{a}$, David George ${ }^{r}$, Edwin Grandcourt ${ }^{\mathrm{s}}$, Ross \\ Hill $^{t}$, David M. John ${ }^{r}$, David A. Jones ${ }^{u}$, Shashank Keshavmurthy ${ }^{n}$, Huda Mahmoud ${ }^{v}$, Mahdi \\ Moradi Och Tapeh ${ }^{\mathrm{w}}$, Pargol Ghavam Mostafavi ${ }^{\mathrm{x}}$, Humood Naser ${ }^{\mathrm{y}}$, Michel Pichon ${ }^{\mathrm{z}}$,aa , Sam \\ Purkis $^{\mathrm{ab}}$, Bernhard Rieglab, Kaveh Samimi-Namin ${ }^{\mathrm{ac}, \mathrm{ad}}{ }^{\mathrm{ab}}$, Charles Sheppard ${ }^{\mathrm{ae}}$, Jahangir Vajed \\ Samieiad, Christian R. Voolstra ${ }^{\text {af }}$, and Joerg Wiedenmann ${ }^{\text {h }}$
}

aSchool of the Environment, University of Technology, Sydney, P.O. Box 123, Broadway NSW 2007, Australia bNew York University - Abu Dhabi, P.O. Box 129188, Abu Dhabi, United Arab Emirates 'School of Marine and Tropical Biology and ARC, Centre of Excellence for Coral Reef Studies, James Cook University, Townsville, Qld 4811, Australia dKuwait Institute for Scientific Research, P.O. Box 24885, Safat 13109, Kuwait environmental Assessment Department, Ministry of Environment, Doha, P.O. Box 39320, State of Qatar, Qatar ' Ministry of Culture, Bahrain, P.O. Box 2199, Manama, Bahrain 9Biology Department, Woods Hole Oceanographic Institution, Woods Hole, MA 02543, USA hNational Oceanography Centre, University of Southampton, Ocean and Earth Sciences, SO14 3ZH, United Kingdom 'Rosenstiel School of Marine and Atmospheric Science, University of Miami, 4600 Rickenbacker Causeway, Miami, FL 33149, USA 'American University of Sharjah, Universities City, P.O. Box 26666, Sharjah, United Arab Emirates ${ }^{k}$ Emirates Diving Association, P.O. Box 33220, Dubai, United Arab Emirates IInstitute of Biomedical Sciences Abel Salazar (ICBAS), University of Porto (U. Porto), Rua de Jorge Viterbo Ferreira 228, Porto, Portugal mInstituto de Ciências Atmosféricas, Universidade Federal de Alagoas, Maceió-AL 57072-970, Brazil "Biodiversity Research Centre/Taiwan International Graduate Program-Biodiversity, Academia, Sinica, Nangang, Taipei 115, Taiwan 'Natural Sciences, Bishop Museum, 1525 Bernice Street, Honolulu, HI 96817, USA PHawai'i Institute of Marine Biology, P.O. Box 1346, Kane'ohe, HI, USA 9Faculty of Biological Sciences, Shahid, Beheshti University, Tehran, Iran 'Natural History Museum, Life Sciences Department, Cromwell Road, London SW7 5BD, United Kingdom 'Environment Agency - Abu Dhabi, P.O. Box 45553, Abu Dhabi, United Arab Emirates ${ }^{\mathrm{t} C e n t r e ~ f o r ~ M a r i n e ~ B i o-I n n o v a t i o n ~ a n d ~ S y d n e y ~}$ Institute of Marine Science, School of Biological, Earth and Environmental Sciences, The University of New South Wales, Sydney, 205230 NSW, Australia upersonal Postal, Box 443, Ctra. Cabo la Nao, (Pla) 124-6, 03730 Javea, Alicante, Spain vKuwait University, Faculty of

(C) 2013 Elsevier Ltd. All rights reserved.

*Corresponding author. david.feary@uts.edu.au, david.feary@ gmail.com (D.A. Feary).

Appendix A. Supplementary material

Supplementary data associated with this article can be found, in the online version, at http://dx.doi.org/10.1016/j.marpolbul. 2013.02.038 
Science, P.O. Box 5969, Safat 13060, Kuwait wArtemia and Aquatic Animals Research Institute, Urmia University, Iran ${ }^{\times}$Department of Marine Biology, Graduate School of, Marine Science and Technology, Science and Research Branch, Islamic Azad University, Tehran, Iran YDepartment of Biology, College of Science, University of Bahrain, P.O. Box 32038, Bahrain zJames Cook University, Townsville, Qld 4811, Australia aaMuseum of Tropical Queensland, 70-102 Flinders Street, Townsville, Qld 4810, Australia abNational Coral Reef Institute, Nova Southeastern, University, Dania Beach, FI 33004, USA acDepartment of Marine Zoology, Naturalis Biodiversity Center, P.O. Box 9517, 2300 RA Leiden, The Netherlands adMarine Biology Division, Iranian National Institute for Oceanography, P.O. Box 14155-4781, Tehran, Iran aeSchool of Life Sciences, University of Warwick, Coventry CV4 7AL, United Kingdom afRed Sea Research Center, KAUST (King Abdullah, University of Science and Technology), Thuwal, Saudi Arabia

\section{Abstract}

Expert opinion was assessed to identify current knowledge gaps in determining future changes in Arabian/ Persian Gulf (thereafter 'Gulf') coral reefs. Thirty-one participants submitted 71 research questions that were peer-assessed in terms of scientific importance (i.e., filled a knowledge gap and was a research priority) and efficiency in resource use (i.e., was highly feasible and ecologically broad). Ten research questions, in six major research areas, were highly important for both understanding Gulf coral reef ecosystems and also an efficient use of limited research resources. These questions mirrored global evaluations of the importance of understanding and evaluating biodiversity, determining the potential impacts of climate change, the role of anthropogenic impacts in structuring coral reef communities, and economically evaluating coral reef communities. These questions provide guidance for future research on coral reef ecosystems within the Gulf, and enhance the potential for assessment and management of future changes in this globally significant region.

\section{Keywords}

Persian Gulf; Arabian Gulf; Coral Reefs; Expert; Assessment; Research Gap

\section{Introduction}

The Gulf is a semi-enclosed marginal sea, connected to the Gulf of Oman (also known as the 'Sea of Oman') through the $56 \mathrm{~km}$ wide Strait of Hormuz (Chao et al., 1992; Sheppard et al., 1992; Coles, 2003). There has been a rapid and substantial increase in scientific interest within the region, especially its marine environment and the physical extremes in which its marine communities (especially coral reefs) have evolved (reviewed in Khan et al. (2002), Hamza and Munawar (2009), Sheppard et al. (2010), Sale et al. (2011), and Riegl and Purkis (2012)). In an era of unparalleled changes in global oceanic climate, understanding the potential implications of global changes on ecologically, economically and socially important coastal coral reef ecosystems will be vital in developing adequate management and conservation measures to cope with such changes. Within the Gulf, the coral reef ecosystem is characterized by some of the world's most extreme environmental conditions, with salinity often $>45$, and the highest variability in annual temperature encountered by 
coral reefs globally (Sheppard et al., 1992; Riegl, 2001; Sheppard and Loughland, 2002). Consequently, investigating coral reefs that exist in marginal environments (i.e. regions that have naturally extreme physical factors structuring their populations) will effectively inform about the limits of adaptation, acclimation, and resilience (Feary et al., 2010; Purkis et al., 2011; Riegl et al., 2011).

There is increasing interest in developing research programs within the Gulf to understand the importance of physical extremes in structuring its coral reef communities (Feary et al., 2010; Sale et al., 2011; Burt et al., 2011; Riegl et al., 2011). Thus it is vital that research programs have clear hypotheses and predictions. Most research on coral reef communities within the Gulf has historically been based around baseline assessments, usually associated with large-scale coastal development projects (Price, 1982; Coles and Tarr, 1990; Sheppard et al., 1992, 2010; Fadlallah et al., 1993; Harrison, 1995; Coles, 2003; Purkis and Riegl, 2005; Purkis et al., 2005; Burt et al., 2009). However, recent research has begun to focus on understanding mechanisms important in structuring marine communities, rather than simply categorizing these communities by their biotope (Burt et al., 2008, 2010, 2011; Richlen et al., 2010; Bauman et al., 2011). In addition, it is important to understand that research being undertaken in the Gulf on its coral reef communities can help with examining questions of global significance. Here we present a list of critical research areas and research questions that would advance our understanding of the potential changes in Gulf coral reef ecosystem. We also summarize current research strengths and weaknesses within the Gulf research community.

\section{Methods}

Data were obtained by inviting managers and academics to submit up to five questions that represented feasible research projects and information gaps for understanding future changes within Gulf coral reef ecosystem. Academics were invited to participate if they had authored or co-authored at least two peer-reviewed articles or reports on the Gulf or adjacent regions within the last 20 years. Managers were defined as those representing key environmental agencies within countries bordering the Gulf, who were responsible for making management/policy decisions in relation to the environmental management of the Gulf ecosystem. Of 49 individuals invited to contribute, 31 provided 71 distinct questions. This represented expert opinion from people of 30 institutions from seven countries who had conducted, or were conducting, research in the Gulf (all littoral States except Iraq). All invited managers and academics were participants in the 'Coral Reefs of the Gulf' conference, Abu Dhabi, February 2012.

Keywords in the 71 questions were used to identify 12 major research areas in the Gulf:

i. Abiotic interactions/factors structuring Gulf coral reef communities

ii. Anthropogenic activities structuring Gulf coral reef communities

iii. Biological and ecological processes structuring Gulf coral reef communities

iv. Climate change impacts on Gulf coral reef biology and ecology

v. Connectivity of Gulf coral reef communities

Mar Pollut Bull. Author manuscript; available in PMC 2014 August 01. 
vi. Disease biology within Gulf coral reef communities

vii. Economic evaluation of Gulf coral reef communities

viii. Evolution of Gulf coral reef communities

ix. Marine protected area development

x. Monitoring and ecological surveys of coral reef community structure within the Gulf

xi. Oceanographic factors structuring Gulf coral reef communities

xii. Coral reef restoration and management

Participants were required to rank the 12 areas in order of perceived importance (from 1 to 12 [most to least important]). To examine the range of expertise encompassed within this assessment, but also determine how expertise affected the evaluation of research areas, each participant was asked to list up to three of their 'research strengths'. Research strengths were used to classify participants into particular research areas. The potential influence of expertise on the perceived importance of research areas was then assessed by examining the relationship between the number of participants within a research area and the median importance score given to that area using linear regression (GLM procedure, SPSS) (sensu Wilson et al., 2010). To assess whether the expertise of participants also influenced the breadth of proposed questions, questions were classified into the research areas they related to, and the relationship between the number of participants and the number of questions in an area was determined using linear regression. Research strengths of participants and content of questions often related to more than one research area, and if so, they were classified into multiple areas.

The value of proposed research questions was assessed by asking participants to rate each question (presented in a random order) in terms of four attributes:

1. Does this research identify a gap in our current knowledge base?

2. Is this research question of high priority, needing to be answered immediately?

3. Could this research question be developed into a feasible research project within the Gulf?

4. Is this research question of broad ecological scope (applicable to multiple species and reefs throughout the Gulf)?

Participants were asked to give each question a score $(1=$ very low; $2=$ low; $3=$ medium; 4 = high; 5 = very high) for how well the question addressed each attribute. Attributes 1 and 2 (knowledge gap, priority) were considered a measure of the importance of proposed questions, while attributes 3 and 4 (feasibility, scope) were considered a measure of the resource-efficiency of proposed questions. Median scores of questions within research areas were examined to identify research areas with the most important and resource-efficient questions, and to assess whether the expertise of participants biased their scoring of questions from outside their own research strengths. Individual questions with a median score of either 'high' or 'very high' for all four attributes were identified as critical for 
understanding future changes in the Gulf, i.e. those questions which were considered both highly important and an efficient use of resources. Questions with a median score of either 'high' or 'very high' for the knowledge gap attribute and at least 'medium' for all other attributes were identified as important for Gulf research, but not critical.

\section{Results}

\subsection{Research areas and participants}

There were clear differences in the perceived importance of research areas (Fig. 1). Biological and ecological processes, the potential role of climate change, and anthropogenic activities on coral reefs were considered to be most important, while areas considered least important were disease biology, the evolution of Gulf coral reef communities and the economic evaluation of Gulf coral reef ecosystems (Fig. 1). However, there was an uneven distribution of participants among reported research strengths. Overall, approximately $40 \%$ of participants listed their research strengths in the areas of biological, ecological and anthropogenic processes structuring Gulf coral reef communities. Less than 5\% of scientists listed their research strengths as being in areas of abiotic interactions, marine population connectivity and coral disease; no participants listed their research strength as economic evaluation of Gulf coral reef ecosystems (Fig. 1). This bias in the designation of research strengths among participants influenced the perceived importance of research areas, with a positive relationship found between the number of scientists in a research area and the median importance score for that research area $\left(R^{2}=0.34, F_{1,11}=5.137, P=0.047\right)$. However, several research areas with few participants received relatively high median importance scores (Fig. 1). These were climate change impacts on Gulf coral reef communities, development of marine protected areas, understanding abiotic factors that structure Gulf coral reef communities, and the connectivity of Gulf coral reef communities (Fig. 1).

\subsection{Research questions and participants}

The median score of research questions among research areas ranged from 'medium' to 'high' in all four evaluation attributes (Fig. 2). Questions that related to the research areas of anthropogenic activities and reef restoration and management received the highest scores across all evaluation categories, and although the area of economic evaluation also appeared to score highly, this represented the results of a single question (Fig. 2, and see Supplementary data). Questions relating to biological and ecological factors, oceanography and coral disease biology received the lowest scores across all evaluation categories (Fig. 2). The low scores for questions relating to biological and ecological processes were unexpected, given the high proportion of participants that listed these research areas as their research strengths (48\%). However, such low scores for these questions may relate to the diversity of questions within these research areas (see Supplementary data). Research questions encapsulated a range of topics, including fisheries, coral reef benthic development, larval behavior and ecology, herbivory, analysis of biotypes, etc. Such a wide range of questions within these research areas will have led to substantial disparity in ranking the importance of different questions between participants; such disparity will then have moderated the overall scores for these research areas. The research strengths of participants 
also influenced the range and scope of research questions proposed, with a positive relationship found between the number of participants working in a research area and the number of research questions relating to that area $\left(R^{2}=0.44, F_{1,11}=7.909, P=0.018\right)$. Exceptions were the areas of anthropogenic activities and abiotic interactions, which had relatively few, and relatively many, questions compared to the number of participants listing these as their research strengths, respectively (Fig. 3). Despite bias in the types of questions proposed, questions were scored relatively evenly across research areas (Fig. 2).

\subsection{Scoring of research questions}

3.3.1. Critical research questions-Of the 71 research questions, 10 had a median score of 'high' or 'very high' in all four of the assessment attributes: they identified a substantial gap in our current knowledge base, they were judged a high priority, requiring immediate application, they were deemed to be feasible to develop into a research project within the Gulf, and they were considered to be broad in their ecological scope. These 10 questions (in no specific order) are listed below under their research themes.

\subsection{Climate change impacts on Gulf biology and ecology}

1. Predictions based on experimental and field observations indicate that the combined effects of rising temperatures and ocean acidification could increase the frequency of bleaching events and reduce coral calcification by up to $80 \%$ of modern values (Erez et al., 2011). If rates of $\mathrm{CaCO}_{3}$ production by coral and other reef calcifiers cannot keep up with rates of erosion, the majority of coral reefs could switch from net accreting to net eroding structures. Given that the majority of hard corals in the Gulf do not build reefal frameworks, they could potentially be threatened by a shortage of suitable habitat, over next $40-50$ years, which they rely for colonization due to changes in water chemistry (Purkis et al., 2011). What is the present condition of seawater acidity/alkalinity in the Gulf, how do they compare to tropical Pacific Ocean conditions, and how will increased dissolved $\mathrm{CO}_{2}$ affect coral growth in the Gulf?

2. The Gulf functions as a negative estuary where high evaporation rates causes salinities well above open ocean values that exceed tolerances experimentally determined for corals from other regions. However, even Gulf corals have demonstrated limits to elevated salinity, and it has been shown that both coral species diversity and general benthic diversity decrease with increasing salinity in the Gulf (Coles, 2003). How will overall and local salinities in the Gulf be affected in the next century by anticipated increasing temperatures due to climate change, and by increased discharge of high salinity brines from massive desalination plants built to provide freshwater to developing Gulf countries?

\subsection{Connectivity of Gulf coral reef populations}

1. Research has shown that source populations for coral reefs throughout the Gulf can be substantial distances from sink areas. For example, in Qatar's exclusive economic zone source populations are approximately $110 \mathrm{~km}$ offshore to the north and east of Qatar, while within southern UAE there is a distinct west-to-east 
decline in the abundance of coral recruits (Burt et al., 2011). What proportion of coral recruits originate from local reefs throughout the Gulf, and what proportion comes from outside the Gulf? Are there distinct source areas of coral planulae for Gulf coral reefs and to what degree is regional connectivity supporting recovery of degraded coral reefs in the Gulf?

2. The degree to which marine populations are connected has important consequences for how coral reef populations persist, how they respond to natural and anthropogenic disturbances, and how they can be managed (Sale et al., 2005). Currently our understanding of connectivity within the Gulf is grossly limited. What is the genetic connectivity of coral reef populations at multiple spatial scales within the Gulf?

\subsection{Monitoring and ecological surveys of community structure within the Gulf}

1. A problem from which the Gulf suffers is a shifting baseline (Sheppard et al., 2010). The accumulation of many construction projects adds up to major changes even when one project on its own may not (Sale et al., 2011). Today it is difficult to find any meaningful baselines, not only because of ongoing, intensive constructions, but also because of several recent episodes of marine mortality from seawater warming. Against what measures should reefs be assessed when baseline environmental impact assessment studies wish to measure change? Where in the Gulf is there a good baseline for coral reefs?

2. The Gulf experiences extreme environmental conditions, with temperatures ranging from $\sim 35^{\circ} \mathrm{C}$ in the summer, the largest temperature range known to be experienced by reefs (Kleypas et al., 1999; Purkis and Riegl, 2005; Sheppard et al., 2010; Riegl et al., 2011). In addition, reefs are exposed to high salinity (>45 ppt in places) and turbidity. Such conditions would result in mass mortality of reef fauna in other regions. There is very limited understanding of the mechanisms used by reef fauna throughout the Gulf to overcome the stress posed by the natural physical environment. What are the physiological processes enhancing survivorship of reef fauna in the extreme Gulf environment? How does the physiological sensitivity of reef fauna differ temporally and spatially in the Gulf?

\subsection{Marine protected area development}

1. There is still a lack of information about the biodiversity of coral reefs in the Gulf. For example, there are approximately 36 species of hard corals found throughout the Iranian region (Wilkinson, 2008), however there is increasing evidence that this number is higher than previously thought (Moradi et al., 2009; Riegl et al., 2012; Shojae et al., 2010; Vajed-Samiei et al., in press). Similar pattern also exist for octocorals of the Gulf (Samimi-Namin and van Ofwegen, 2009, 2012). The Gulf is a stressful and disturbed environment with low species richness compared to most parts of the Indian Ocean, but has a high beta-diversity (Price, 2002). Therefore, the identification and conservation of hotspots of coral reef biodiversity is one of the basic priorities in the declining Gulf. Which coral reef habitats represent the hotspots of biodiversity in the Gulf? 


\subsection{Reef restoration and management}

1. Given the high level of coastal development in the Gulf region it is essential to develop a toolkit in order to facilitate resiliencebased management in coastal development areas (Sale et al., 2011). The current lack of baseline studies makes the assessment, monitoring and management of coastal communities' unclear, allowing ongoing coastal development without control regarding the potential environment impact. Do we have sufficient knowledge of the biology and ecology of the existing flora and faun of coral reefs in the Gulf to be able to recommend measures to stabilise their deterioration in the face of future climate change impacts?

2. Reefs in the Gulf have been impacted by a number of recent severe bleaching events, with limited to no recovery (Baker et al., 2008; Burt et al., 2008; Burt et al., 2011). Limited recovery may be due to a combination of decreased reproductive output and associated recruitment limitation or high post-settlement mortality as a result of the relatively extreme environmental conditions and/or increases in anthropogenic stressors (Gleason and Hofmann, 2011). This is also likely to vary among taxa as a result of differences in tolerance thresholds. Recent studies across $\sim 400 \mathrm{~km}$ of the southern basin of the Gulf show relatively high densities of coral recruits on tiles, even on some of the most degraded reefs, suggesting that recovery is being inhibited by post-recruitment factors. What role does coral settlement versus post-settlement mortality play in reef maintenance/ recovery in the Gulf?

\subsection{Economic evaluation of Gulf marine communities}

1. The economic valuation of goods and services associated with natural ecosystems has grown rapidly in the past two decades in response to accelerating impacts from human activities and climate change (e.g., Costanza et al., 1997; Moberg and Folke, 1999). Coral reefs are considered a particularly valuable ecosystem in many tropical countries due to their role in providing food, tourism revenue, nursery habitat, coastal protection, and a suite of other benefits (Berg et al., 1998). Despite rapid growth in this field in recent years, there has been limited development of economic valuation of natural ecosystems in the Gulf. Given the widespread degradation of reefs due to coastal development, ports, industrial infrastructure and desalination facilities (Sheppard et al., 2010; Sale et al., 2011), it is clear that an economic valuation would be a useful tool for conservation and management. Can economic valuation be used as a tool for coral reef conservation in the Gulf?

3.9.1. Important research questions-Within the 71 research questions assessed by participants, there were 22 that had a median score of either 'high' or 'very high' in the knowledge gap category, and at least 'medium' in the categories of feasibility, ecological scope and priority. These 22 research questions encapsulated nine of the 12 research areas (see Fig. 1 for full list of research areas), and were dominated by research questions on biological and ecological, climate change and anthropogenic process areas. 


\subsection{Biological and ecological processes structuring Gulf marine communities}

1. There have been substantial changes to southern Gulf reefs following the 1996 and 1998 mass bleaching events (George and John, 1999; Riegl, 2002, George and John, 2005). Increased abundances and diversity of filter-feeding sessile invertebrate groups (e.g., sponges and tunicates), substantial increases in sea urchin abundance on coralline algal covered dead coral (Riegl et al., 2011) and seaweeds replacing hard corals in some areas (John and George, 2003) have been found. In addition, increases in yellow-bar angelfish abundance and decreases in grouper abundance have been recorded (Feary et al., 2010) Has the phase-shift from coraldomination on some shallow reefs in the southern Gulf resulted in a marked increase in certain other invertebrate groups? Similarly do changes in physical structure of certain types of coral reef have an impact on more mobile fauna, including fish? What is the impact on coral reeffauna of the recent change from Acropora coral dominance to algal dominance in sheltered shallow reef areas?

2. Healthy reefs are in a delicate balance between reef growth and reef bioerosion, with net reef production only marginally ahead of net reef loss (Glynn, 1997). In disturbed reefs, bioerosion processes destroy the reef framework faster than it is produced (Glynn, 1997). Given the environmental and anthropogenic stressors present in the Gulf (Sheppard et al., 2010), understanding the dynamics of this balance is essential. Are the reefs of the Gulf in a healthy dynamic balance between reef growth and reef bio-erosion?

3. Most reef studies and monitoring programs assess the state of the reefs by estimating the percentage coverage of major benthic organisms, or by examining coral colony size-frequency distributions. Few studies examine the key ecological processes that drive the state variables. The basic processes that determine population dynamics are reproduction, recruitment, post-settlement survival, colony growth, and partial and total mortality. Yet, many of these key ecological processes have rarely been investigated in the Gulf. We still know little about population processes and how they vary spatially, seasonally and under different environmental conditions within the Gulf. We understand even less about differential weightings and sensitivities of populations to slight process changes and the repercussions of those changes on subsequent population trajectories. What are the key ecological processes structuring Gulf communities?

\subsection{Climate change impacts on Gulf biology and ecology}

1. Research suggests that Symbiodinium in clade D are common in the Gulf area and at least partially responsible for high thermotolerance of Gulf corals (Baker et al., 2004; Mostafavi et al., 2007), but clade C Symbiodinium was recently found to be the prevalent symbiont in Abu Dhabi waters (Hume et al., 2013). How do the different symbionts affect the temperature tolerance of the corals? What is the molecular basis for thermotolerance in both corals and zooxanthellae, and what are the tradeoffs of hosting clade D (particularly with respect to ocean acidification, and exposure to seasonal low temperatures)? How are clade D symbionts in Gulf corals related to those found in the western Indian Ocean, 
central-west Pacific (Great Barrier Reef), far eastern Pacific and Caribbean? Who is the key-player in the adaptation to temperature extremes: the zooxanthellae or the host, or is the specific team required?

2. Some fish species in the Gulf are considered to live within $1^{\circ} \mathrm{C}$ of their thermal tolerance limits, at least for some of the year. The tolerance of larval stages may be even more restricted than those of adults, and in some cases, adult distributions may be limited by larval biology (Sheppard et al., 1992). Additionally, demersal reef fish are traditionally considered to undergo little or no seasonal change in abundance because of the relatively constant environmental regimes that typically characterize tropical waters. However, the distribution and abundance of Gulf reef fish is known to vary seasonally (e.g., Coles and Tarr, 1990; Burt et al., 2009), as such, the stock delineation boundaries and management units of the fisheries resources in the Gulf are likely to change as fluctuations in sea water temperatures increase. How will climate change modify the distribution of fisheries resources in the Gulf and what are the associated management implications?

3. The majority of coral species in the Gulf (assuming that names ascribed to the species are correct) are a subset of the much more diverse Indian/Pacific coral fauna. The elucidation of the ecophysiological and genetic mechanisms underlying their tolerance in particular to high temperatures and high salinities experienced in the Gulf will provide insights as to the potential for adaptation/acclimation of corals in other parts of the oceans. Is heat tolerance a result of an adaptation to the "hostile" environmental conditions in the Gulf region or is the combination of specific environmental conditions (salinity, macro/micronutrients, temperature fluctuations, etc.) in fact a prerequisite for survival?

4. Harmful algal bloom events (HABs, commonly called red tides) have been increasing in severity and distribution in the Gulf region, with significant economic, public health, and ecosystem impacts. For example, the 2008 and 2009 Cochlodinium red tide devastated coral reefs, wild and aquaculture fisheries, and shut down desalination plants in the Gulf and Strait of Hormuz (Samimi-Namin et al., 2010; Richlen et al., 2010), while also having substantial negative effects on coral reef communities (Bauman et al., 2010). The continued deterioration of water quality within the Gulf is very likely to lead to more threats of this type, concurrent with the expected expansion of desalination needs within the region. What mechanisms underlie recent increases in the numbers and diversity of harmful algal blooms in the Gulf? What programs are needed to better document the occurrence and distribution of HAB species and their toxins in the Gulf region, and to develop management and mitigation strategies to reduce impacts to both natural environments and man-made developments?

\subsection{Anthropogenic activities structuring Gulf marine communities}

1. A critical concern associated with the extensive growth of Gulf countries is the development of desalination plants, and the hypersaline discharge associated with such plants (Miri and Chouikhi, 2005). Countries bordering the Gulf rely heavily 
on desalination for potable water (Hoepner and Lattemann, 2002), with some of the largest desalination plants in the world. These plants pump a concentrated saline discharge into coastal waters, which increase salinity, temperature, turbidity and lower oxygen compared to ambient water conditions (Del-Pilar-Ruso et al., 2008). With such high levels of desalination use, can we define an urban contribution to changes in abiotic conditions within the Gulf? Will such development of desalination plants have a regional and/or national effect on Gulf waters?

2. Most fisheries in the Gulf are either fully or over exploited (Morgan, 2006; Grandcourt, 2008) and pressure on the resource base has been exacerbated by habitat loss and fragmentation associated with coastal development (Shallard and Associates, 2003). To date, assessments of fisheries resources in the Gulf have only taken into account the direct impacts of the fisheries themselves. What are the impacts of habitat loss and fragmentation for fisheries resources in the Gulf?

3. Recruitment, growth and natural mortality are fundamental demographic processes that structure fish populations and determine productivity.With the increasing use of seawater for desalination and cooling, both salinity and temperature in the Gulf are increasing. As many species are close to their environmental tolerance limits (Sheppard et al., 1992) the physiological implications of these changesmaybe profound in terms of fisheries productivity. As such, an understanding of how predicted increases in temperature and salinity will affect demographic processes and fisheries productivity is required for resourcemanagement planning and decision-making. In what way will increases in salinity and temperature impact demographic processes and the productivity of important fisheries resources in the Gulf?

4. Oil pollution, breakwater construction, sedimentation caused by coastal developments, dredging, fishing, extensive anchor damage and discharge of nutrients and sewage are the major local threats to coral reefs of the Gulf (Halpern et al., 2008; Maghsoudlou et al., 2008; Sheppard et al., 2010; Wiedenmann et al., 2012). Despite this, there is no comprehensive study regarding the effects of such pressures on the ecosystem and/ or colony level characteristics of coral reef communities. How do local threats affect coral reefs within the Gulf? How do coral communities change through time and space in natural versus impacted sites? What is the capacity and/or resilience of Gulf marine communities to pollution load (e.g., eutrophication)?

\subsection{Connectivity of Gulf coral reef populations}

1. Few endemic marine species exist in the Gulf (Sheppard et al., 1992; 2000; Samimi-Namin and van Ofwegen 2009, 2012; Riegl et al., 2012), yet whether this is because of the relatively recent isolation of the Gulf or because of mixing through the Strait of Hormuz. How much genetic isolation is there in Gulf species, relative to congeners/conspecifics outside the Gulf?

2. Two seasonally developing gyral systems exist in the northern and southern Gulf. These have the potential to affect genetic connectivity and thus might result in two 
isolated connectivity regimes within the Gulf. Do patterns of genetic connectivity in coral reef communities in the Gulf map onto the physical basis (i.e. surface currents, etc.)?

3. Although the Gulf is connected to the Indian Ocean through the narrow Strait of Hormuz, the majority of species are of the wide Indo-Pacific distribution. However, it is unclear how much genetic exchange occurs. Is the Gulf a source of preadapted coral and zooxanthellae genotypes that could be used for reef restoration or nurseries at sites elsewhere in the region that are cooler, but warming? What potential exists for the export of thermo-tolerant genotypes of either corals or zooxanthellae) from the Gulf?

\subsection{Monitoring and ecological surveys of community structure within the Gulf}

1. The identification of key functional groups of herbivores (both fishes and urchins) that control the establishment and growth of algal communities is important to coral community dynamics. Studies conducted by Mumby et al. $(2006,2007)$ and Mumby and Harborne (2010) on fish and by Carpenter and Edmunds (2006) on urchins showed that elevated grazing activity positively affects the density and diversity of coral recruits settling to reefs. Nevertheless sea urchin grazing can reach destructive levels when densities are high as a result of overfishing or other factors (Bellwood et al., 2004; Tuya et al., 2005). What are the key functional groups of herbivores on Gulf reefs and what are the seasonal changes in their abundance and diversity?

\subsection{Abiotic interactions/factors structuring Gulf marine populations}

1. Heat flux (from the water to the reef) is strongly linked to flow speed $(u)$ over the reef as well as the temperature gradient $(\mathrm{d} T)$. As the Gulf has strong tidal flows, flow speed over the reef may be a dominant controlling factor in temperature associated bleaching effects. What cross-product (udT) occurs in the Gulf, and can we relate regions of bleaching with the cross product? Given that heat flux (from the water to the reef) is strongly linked to flow speed (u) over the reef as well as the temp gradient (dT), what are the temperature gradients within a Gulf reef and in the water masses over a reef? To what extent does the reef control such gradients?

\subsection{Marine protected area development}

1. The rate of coral reef degradation in much of the Gulf is so high that there is the possibility of irreversibly losing coral reef habitats in many areas unless we are able to conserve what we have left (Sheppard et al., 2010; Sale et al., 2011; Van Lavieren et al., 2011). Are the quantity, size, and placement of marine protected areas in the Gulf sufficient to conserve high value areas, and is enforcement rigorous enough to ensure that these are not paper parks?

2. There is a need to understand where critical habitats for commercially exploited species are within the Gulf. For a range of species, understanding the important critical habitats are vital in the development of management strategies (i.e., protected areas), to adequately protect such species. In the Gulf the obvious 
example would be the Hammour Epinephelus coioides. What are the critical nursery habitats for various commercially important species?

3. Linking conservation benefits of MPAs to overall productivity of marine environments is a global concern (Cicin-Sain and Belfiore, 2005). Several marine protected areas have been established in the Gulf, including those within coral reefs (Krupp, 2002). However, how these areas are contributing to the overall productivity of the Gulf has not been investigated. Are marine protected areas in the Gulf contributing to the overall biodiversity and productivity of this region? Should new high-priority regions be identified for possible no-take marine reserves within the Gulf?

\subsection{Reef restoration and management}

1. Throughout the Gulf artificial reefs are frequently deployed to restore/rehabilitate diversity and productivity of the marine environment. However, the effectiveness of these measures in enhancing productivity is rarely investigated (Feary et al., 2011; Sale et al., 2011; Burt et al., 2012). To what extent do coral restoration or rehabilitation activities compensate for loss of quantity or quality of existing species' habitat? Have artificial reefs in the region been successful in restoring significant biodiversity and productivity?

\subsection{Evolution of Gulf coral reef communities}

1. Gulf coral reefs have evolved in one of the most extreme environments globally, but also within one of the most isolated shallow-water coral reef systems in world (Sale et al., 2011). What is the origin and evolution of scleractinian corals in the Gulf?

2. Given the unique ecological structure of coral reefs within the Gulf, it is vital to understand which genes/loci are under adaptive evolution and which of those contribute to the relative thermo-stability of corals. Have there been co-evolution of Gulf corals and their symbionts within the Gulf and will this reveal valuable information on their formation and origins? How do coral genotypes match Symbiodinium genotypes and vice versa? How does the genotypic makeup of a coral host influence the assemblage of algae and vice versa? Are there certain genetic combinations that are favoured over others? Can we detect selection at the level of the individual?

\section{Discussion}

The synopsis and assessment of critical questions for Gulf coral reef communities identified 10 research questions that were both scientifically important (i.e., filled a knowledge gap and were a priority question to answer), and were also efficient in their resource use (i.e., highly feasible and ecologically broad). These research questions not only encapsulated a range of research shown to be of high relevance to understanding the role of change in structuring Gulf coral reef communities (e.g., Sheppard et al., 2010; Sale et al., 2011; Rieg1 and Purkis, 2012), but are also consistent with research identified as globally important in recent reviews on coral reef resilience and conservation. For example, there have been 
numerous reviews on the role of climate change in structuring benthic tropical communities, with deciphering the role of $\mathrm{CaCO}_{3}$ production in structuring coral reefs deemed vital in the midst of substantial changes in global acid-base regulation (Hoegh-Guldberg, 1999, 2007; Hughes et al., 2003; Baker et al., 2008). In addition, there has been an increase in research arguing for the importance of understanding potential connectivity between source and sink populations within coral reef communities (Jones et al., 1999; Cowen et al., 2000; Dulvy et al., 2003; Almany et al., 2007), while the interpretation of the marine community structure in light of potential shifts in community 'baseline' is now considered essential in understanding the role of perturbations in structuring marine communities (Pauly, 1995; Folke et al., 2004; Baum and Myers, 2004; Knowlton and Jackson, 2008). Similar to the recommendations of global reviews, our assessment found that research priorities for coral reef communities in the Gulf were not focused on development-based, or anthropogenic activities, which is surprising given that recent research has focused almost entirely on this area. Recent assessments of the Gulf, which have focused almost entirely on the role of coastal development in structuring Gulf coral reef ecosystems, have shown that cumulative impacts and increasing exploitation are resulting in substantial worsening of the Gulf's health (Sheppard et al., 2010, 2012; Sale et al., 2011, Grandcourt, 2012; Burt et al., 2012).

As shown in several participant-driven research priority assessments, participants are likely to rate research programs more highly if they are broadly similar to their own research strengths (Sutherland et al., 2009; Wilson et al., 2010). Despite this positive relationship between participant's research strength and their assessment of research needs within the Gulf, there were several research areas that were deemed important for understanding the future Gulf ecosystem, which did not substantially overlap with participant's research strengths. The present assessment has shown that independent of research strength, there is wide interest in understanding the ecological structure of Gulf marine communities, with research questions centered on understanding the biological and ecological processes important in structuring Gulf coral reef communities, in addition to their monitoring and surveys, being some of the most well-developed of research areas. The perceived importance of understanding Gulf marine communities with respect to changing climatic conditions was relatively high, and the number of questions focused on understanding the connectivity of Gulf coral communities was also proportionally higher than expected.

However, the research area of abiotic interactions and factors important in structuring Gulf marine communities had the largest difference between the number of proposed questions and the number of participants listing this as their research strength. This difference in the ratio of research strengths to research questions proposed shows the perceived importance of understanding the effect of abiotic factors on Gulf marine communities (Coles, 1988, 2003; Riegl, 2001; Swift and Bower, 2003; Riegl et al., 2011).

This assessment also found that there was substantial interest in understanding the mechanisms controlling the function of Gulf coral reef ecosystems. Although there is a paucity of information on the range of research expertise within the Gulf over the last three decades, the published research on the Gulf region has been focused on monitoring programs, with a distinct lack of research examining the ecological mechanisms important in structuring Gulf coral reef communities (Sheppard et al., 1992, 2010; Khan, 2007; Sale et al., 2011). However, this predominance of monitoring- based research has slowly decreased 
over the last 10 years, with an increase in the number of publications focusing on more process-orientated research questions (Riegl and Purkis, 2005, 2009; Feary et al., 2010; Burt et al., 2011; Purkis et al., 2011; Riegl et al., 2011). This switch in research interest within the Gulf has come about through an increase in the number and diversity of international research institutions developing within the Gulf (Sheppard et al., 2010; Sale et al., 2011), as well as an international interest in the Gulf as a model for future changes in global ocean climate (Riegl et al., 2011; Purkis et al., 2011). For example, future climate change scenarios predict increases in tropical oceanic temperatures of $1-3^{\circ} \mathrm{C}$ by 2099 , which will have substantial negative effects on coral reefs globally. However, Gulf corals already exist in this future thermal environment and have survived several severe bleaching events (Riegl, 2001, 2002, 2003; Burt et al., 2009; Riegl et al., 2011). In addition, the associated fish communities are relatively diverse and have mean densities comparable to other equatorial reef fish communities (Grandcourt, 2012). Therefore, Gulf coral populations, including the reef associated fauna, may be invaluable for examining the potential phenotypic and genotypic response of tropical reef communities to climate change (Feary et al., 2010; Burt et al., 2011; Purkis et al., 2011; Riegl et al., 2011; Hume et al., 2013).

\subsection{Development of collaborative research within the Gulf}

The present publication represents an unprecedented move of the scientific community concerned with marine research in the Gulf to join forces and tackle important scientific problems. Although there is a relatively long history of scientific collaboration within and outside the Gulf region (i.e., recent and ongoing work on various aspects of Symbiodinium and coral taxonomy and ecology, pers comm S. Keshavmurthy), how will the key research areas within this paper be developed to achieve success in the long run? We propose a number of key objectives that may enhance the development of marine research within the Gulf. This by no means a comprehensive review of the methods which will stimulate research within the Gulf, but may map a way forward for Gulf research to achieve success.

The diversity and scope of research questions proposed by participants within the current assessment is indicative of the international scope of researchers working within, and interested in understanding the Gulf coral reef ecosystems. Although all of the participants within this assessment have worked, or are working within the Gulf, approximately $50 \%$ of participants are not permanently based in research institutions within the Gulf region (Sale et al., 2011; Van Lavieren et al., 2011). However, this high level of international expertise is inherent within the Gulf research culture, in which foreign experts remain in the region for months to years, but do not permanently reside in the Gulf (Sale et al., 2011). There needs to be a much stronger intent to bridge the disconnection between the level of international interest in the Gulf and local research expertise. Developing the awareness of marine issues within schools, developing tertiary education that encompasses marine studies, and then developing jobs in marine research are all vital in developing the research expertise within the Gulf.

Effective communication and collaboration among research teams across the region will be required to ensure all key areas of research are investigated, and to avoid redundancy ('doubling up'). In addition to cooperation among individual researchers, there is the need to 
development cooperative relationships between organizations, both within and across nations (i.e. through the development of MOUs); this is analogous to the objectives set out in the Regional Organization for the Protection of the Marine Environment (ROPME). In addition, government-funded programs promoting the exchange of researchers between nations and provision of funding for collaborative research projects may be used to facilitate international cooperation on Gulf research. Lastly, the organization of regular conferences and workshops for both scientists and resource managers will ensure that development in key areas of Gulf research is quickly and effectively communicated.

Overall there is a need to create a research society within the Gulf that includes various stakeholders concerned with the science and conservation of coral reefs in the Gulf and adjacent regions. In this respect, the Mideast Coral Reef Society (MCRS) Initiative has been launched recently (http://www.mideastcrs.org/). The MCRS initiative is jointly hosted by the New York University Abu Dhabi and the University of Southampton and is funded by the Natural Environment Research Council, UK. This society will be an association of researchers and members of governmental, non-governmental, academic, industry and private sector organizations with an interest in a broad range of aspects of Middle Eastern reefs. The MCRS Initiative is already supported by more than 50 representatives of high profile, international academic and non-academic organizations, and will promote collaboration among researchers and knowledge exchange with stakeholders outside academia with the aim to generate a deep understanding of the functioning of these unique ecosystems, and to promote their conservation and sustainable use.

\section{Supplementary Material}

Refer to Web version on PubMed Central for supplementary material.

\section{Acknowledgments}

This manuscript is a direct result of the 'Coral Reefs of the Gulf' conference, hosted and sponsored by the New York University - Abu Dhabi Institute in Abu Dhabi, February 2012. In addition, D.A. Feary was supported by a Chancellors Postdoctoral Fellowship within the University of Technology, Sydney, D.M. Anderson was provided support from the Ministry of Environment and Water, United Arab Emirates, and the Woods Hole Center for Oceans and Human Health (NSF/NIEHS), E. Grandcourt was supported by Environment Agency - Abu Dhabi, H. Mahmood was supported by Kuwait University, C.R. Voolstra was supported by a KAUST AEA 3 Joint Collaborative Research award 'the Natural History Museum, London and the Abu Dhabi Company for Onshore Oil Operations (ADCO) are thanked by D.M. John and J.D. George for supporting their research in the UAE' research at Naturalis Biodiversity Center and partial field work for K. Samimi-Namin was supported by Schure-BeijerinckPoppingfonds (KNAW), Alida Buitendijkfonds, Jan Joost ter Pelkwijkfonds, and Martin-Fellowship. The Alfred P. Sloan Foundation and the Census of Marine Life are gratefully acknowledged for the research grant provided to K. Samimi-Namin; in this regard N. D'Adamo (UNESCO, ICO, Perth), M. Claereboudt (Sultan Qaboos University), J.H. Ausubel (Rockefeller University), and P. Miloslavich (Universidad Simón Bolívar) are appreciated for their continuous support and encouragement. The Mideast Coral Reef Society Initiative is funded by the NERC (NE/ K00641X/1 to J. Wiedenmann).

\section{References}

Almany GR, Berumen ML, Thorrold SR, Planes S, Jones GP. Local replenishment of coral reef fish populations in a marine reserve. Science. 2007; 316:742-744. [PubMed: 17478720]

Baker AC, Starger CJ, McClanahan TR, Glynn PW. Corals' adaptive response to climate change. Nature. 2004; 430:741. [PubMed: 15306799] 
Baker AC, Glynn PW, Riegl B. Climate change and coral reef bleaching: an ecological assessment of long-term impacts, recovery trends and future outlook. Estuar Coast Shelf Sci. 2008; 80:435-471.

Baum JK, Myers RA. Shifting baselines and the decline of pelagic sharks in the Gulf of Mexico. Ecol Lett. 2004; 7:135-145.

Bauman AG, Burt JA, Feary DA, Marquis E, Usseglio P. Harmful algal blooms: an emerging threat to coral reef communities? Mar Pollut Bull. 2010; 60:2117-2122. [PubMed: 20864137]

Bauman AG, Baird AH, Cavalcante GH. Coral reproduction in the world's warmest reefs: southern Gulf (Dubai, United Arab Emirates). Coral Reefs. 2011; 30:405-413.

Bellwood DR, Hughes TP, Folke C, Nystrom N. Confronting the coral reef crisis. Nature. 2004; 429:827-833. [PubMed: 15215854]

Berg H, Öhman MC, Troëng S, Lindén O. Environmental economics of coral reef destruction in Sri Lanka. Ambio. 1998; 27:627-634.

Burt J, Bartholomew A, Usseglio P. Recovery of corals a decade after bleaching event in Dubai, United Arab Emirates. Mar Biol. 2008; 154:27-36.

Burt J, Bartholomew A, Usseglio P, Bauman A, Sale PF. Are artificial reefs surrogates of natural habitats for corals and fish in Dubai, United Arab Emirates? Coral Reefs. 2009; 28:663-675.

Burt J, Feary DA, Usseglio P, Bauman A, Sale PF. The influence of wave exposure on coral community development on large-scale man-made breakwater reefs, with a comparison to a natural reef. Bull Mar Sci. 2010; 86:839-859.

Burt J, Feary D, Bauman A, Usseglio P, Cavalcante G, Sale P. Biogeographic patterns of reef fish community structure in the northeastern Arabian Peninsula. ICES J Mar Sci. 2011; 68:1875-1883.

Burt, J.; Bartholomew, A.; Feary, D. Man-made structures as artificial reefs in the Gulf. In: Riegl, B.; Purkis, S., editors. Coral Reefs of the Gulf: Adaptation to Climatic Extremes. Springer B.V; 2012. p. 171-186.

Carpenter RC, Edmunds PJ. Local and regional scale recovery of Diadema promotes recruitment of scleractinian corals. Ecol Lett. 2006; 9:268-277.

Chao SY, Kao TW, Al-Hajri KR. A numerical investigation of circulation in the Arabian Gulf. J Geophys Res. 1992; 7:11219-11236.

Cicin-Sain B, Belfiore S. Linking marine protected areas to integrated coastal and ocean management: a review of theory and practice. Ocean Coast Manage. 2005; 48:847-868.

Coles, SL. Limitations on reef coral development in the Arabian Gulf: temperature or algal competition?. Proceedings of the Sixth International Coral Reef Symposium; 1988. p. 211-216.

Coles S. Coral species diversity and environmental factors in the Arabian Gulf and the Gulf of Oman: a comparison to the Indo-Pacific region. Atoll Res Bull. 2003; 507:1-19.

Coles SL, Tarr AB. Reef fish assemblages in the western Arabian Gulf: a geographically isolated population in an extreme environment. Bull Mar Sci. 1990; 47:696-720.

Costanza R, d'Arge R, de Groot R, Farber S, Grasso M, Hannon B, Limburg K, Naeem S, O'Neill RV, Paruelo J, Raskin RG, Sutton P, van den Belt M. The value of the world's ecosystem services and natural capital. Nature. 1997; 387:253-260.

Cowen RK, Lwiza KMM, Sponaugle S, Paris CB, Olson DB. Connectivity of marine populations: open or closed? Science. 2000; 287:857-859. [PubMed: 10657300]

Del-Pilar-Ruso Y, De-La-Ossa-Carretero JA, Gimenez-Casalduero F, Sanchez-Lizaso JL. Effects of a brine discharge over a soft bottom Polychaeta assemblage. Environ Pollut. 2008; 156:240-250. [PubMed: 18329770]

Dulvy NK, Sadovy Y, Reynolds JD. Extinction vulnerability in marine populations. Fish Fish. 2003; 4:25-64.

Erez, J.; Reynaud, S.; Silverman, J.; Schneider, K.; Allemand, D. Coral calcification under ocean acidification and global change. In: Dubinksy, Z.; Stambler, N., editors. Coral Reefs: An Ecosystem in Transition. Springer Science; New York: 2011. p. 151-176.

Fadlallah YH, Eakin CM, Allen KW, Estudillo RA, Rahim SA, Reaka-Kudla M, Earle SA. Reef Coral Distribution and Reproduction, Community Structure, and Reef Health (Qatar, Bahrain, Saudi Arabia, Kuwait): Results of the Mt. Mitchell Cruise, May 1992. Mitchell Cruise in the Arabian/ Gulf. 1993; 1:1-28. 
Feary DA, Burt JA, Bauman AG, Usseglio P, Sale PF, Cavalcante GH. Fish communities on the world's warmest reefs: what can they tell us about impacts of a climate change future? J Fish Biol. 2010; 77:1931-1947. [PubMed: 21078099]

Feary DA, Burt JA, Bartholomew A. Artificial marine habitats in the Arabian Gulf: review of current use, benefits and management implications. Ocean Coast Manage. 2011; 54:742-749.

Folke C, Carpenter S, Walker B, Scheffer M, Elmqvist T, Gunderson L, Holling CS. Regime shifts, resilience, and biodiversity in ecosystem management. Annu Rev Ecol Evolut Systemat. 2004; 35:557-581.

George JD, John DM. High sea temperatures along the coast of Abu Dhabi (UAE), Arabian Gulf their impact upon corals and macroalgae. Reef Encounter. 1999; 25:21-23.

George, JD.; John, DM. The status of coral reefs and associated macroalgae in Abu Dhabi (UAE) after recent coral bleaching events. In: Abuzinada, AH.; Joubert, E.; Krupp, F., editors. The extent and impact of coral bleaching in the Arabian region, February 5-9, 2000, Riyadh, Saudi Arabia. NCWCD; Riyadh: 2005. p. 184-200.-202.

Gleason DF, Hofmann DK. Coral larvae: from gametes to recruits. J Exp Mar Biol Ecol. 2011; 408:42-57.

Glynn, P. Eastern Pacific reef coral biogeography and faunal flux: Durham's dilemma revisited. Proceedings of the 8th International Coral Reef Symposium; Panama. 1997. p. 371-378.

Grandcourt, E. Fish and fisheries. In: Al Abdessalaam, TZ., editor. Marine Environment and Resources of Abu Dhabi. Motivate Publishing; Dubai: 2008. p. 200-225.

Grandcourt, E. Reef fish and fisheries in the Gulf. In: Riegl, BM.; Purkis, S., editors. Coral Reefs of the Gulf: Adaptation to Climatic Extremes. Springer; Netherlands: 2012. p. 127-161.

Halpern BS, Walbridge S, Selkoe KA, Kappel CV, Micheli F, D’Agrosa C, Bruno JF, Casey KS, Ebert C, Fox HE, Fujita R, Heinemann D, Lenihan HS, Madin EMP, Perry MT, Selig ER, Spalding M, Steneck R, Watson R. A global map of human impact on marine ecosystems. Science. 2008; 319:948-952. [PubMed: 18276889]

Hamza W, Munawar M. Protecting and managing the Arabian Gulf: past, present and future. Aquat Ecosyst Health Manage. 2009; 12:429-439.

Harrison, PL. Final Report to the United Nations Industrial Development Organization and the United Nations Development Programme. UNIDO and UNDP; Vienna: 1995. Status of the Coral Reefs of Kuwait.

Hoegh-Guldberg O. Climate change, coral bleaching and the future of the world's coral reefs. Mar Freshwater Res. 1999; 50:839-866.

Hoegh-Guldberg O, Mumby PJ, Hooten AJ, Steneck RS, Greenfield P, Gomez E, Harvell CD, Sale PF, Edwards AJ, Caldeira K, Knowlton N, Eakin CM, Iglesias-Prieto R, Muthiga N, Bradbury RH, Dubi A, Hatziolos ME. Coral reefs under rapid climate change and ocean acidification. Science. 2007; 318:1737-1742. [PubMed: 18079392]

Hoepner T, Lattemann S. Chemical impacts from seawater desalination plants-a case study of the northern Red Sea. Desalination. 2002; 152:133-140.

Hughes TP, Baird AH, Bellwood DR, Card M, Connolly SR, Folke C, Grosberg R, Hoegh-Guldberg O, Jackson JBC, Kleypas J, Lough JM, Marshall P, Nyström M, Palumbi SR, Pandolfi JM, Rosen $\mathrm{B}$, Roughgarden J. Climate change, human impacts, and the resilience of coral reefs. Science. 2003; 301:929-933. [PubMed: 12920289]

Hume, B.; D’Angelo, C.; Burt, J.; Baker, AC.; Riegl, B.; Wiedenmann, J. Corals from the Persian/ Arabian Gulf as models for thermotolerant reef-builders: Prevalence of clade C3 Symbiodinium, host fluorescence and ex situ temperature tolerance. Mar Pollut Bull. 2013. http://dx.doi.org/ 10.1016/j.marpolbul.2012.11.032

John, DM.; George, JD. Coral death and seasonal seawater temperature regime: their influence on the marine algae of Abu Dhabi (UAE) in the Arabian Gulf. Proceedings of the International Seaweed Symposium 17; Oxford and New York: Oxford University Press; 2003. p. 341-348.

Jones GP, Milicich MJ, Emslie MJ, Lunow C. Self-recruitment in a coral reef fish population. Nature. 1999; 402:802-804.

Khan NY. Multiple stressors and ecosystem-based management in the Gulf. Aquat Ecosyst Health Manage. 2007; 10:259-267. 
Khan, NY.; Munawar, M.; Price, ARG., editors. The Gulf Ecosystem: Health and Sustainability. Backhuys Publishers; Leiden: 2002.

Kleypas JA, Buddemeier RW, Archer D, Gattuso J, Langdon C, Opdyke BN. Geochemical consequences of increased atmospheric carbon dioxide on coral reefs. Science. 1999; 284:118120. [PubMed: 10102806]

Knowlton N, Jackson JBC. Shifting baselines, local impacts, and global change on coral reefs. PLoS Biol. 2008; 6:e54. [PubMed: 18303956]

Krupp, F. Marine protected areas. In: Khan, NY.; Munawar, M.; Price, ARG., editors. Gulf Ecosystem: Health and Sustainability. 2002. p. 447-473.

Maghsoudlou, A.; Araghi, PE.; Wilson, S.; Taylor, O.; Medio, D. Status of the coral reefs in the ROPME sea area (The Gulf, Gulf of Oman and Arabian Sea). In: Wilkinson, C., editor. Status of Coral Reefs of the World. Global Coral Reef Monitoring Network and Reef and Rainforest Research Center; Townsville, Australia: 2008. p. 79-90.

Miri R, Chouikhi A. Ecotoxicological marine impacts from seawater desalination plants. Desalination. $2005 ; 182: 403-410$.

Moberg F, Folke C. Ecological goods and services of coral reef ecosystems. Ecol Econ. 1999; 29:215233.

Moradi M, Kamrani E, Shokri MR, Ranjbar MS, Hesni MA. First record of two hard coral species (Faviidae and Siderastreidae) from Qeshm Island (Gulf, Iran). Nusantara Biosci. 2009; 2:34-37.

Morgan, G. Country review: Eritrea. In: De Young, C., editor. Review of the State of World Marine Capture Fisheries Management: Indian Ocean. FAO Fisheries Technical Paper No 488. FAO; Rome: 2006. p. 458

Mostafavi PG, Fatemi MR, Shahhosseiny MH, Hoegh-Guldberg O, Loh WKW. Predominance of clade D Symbiodinium in shallow water reef-building corals off Kish and Larak Islands (Gulf, Iran). Mar Biol. 2007; 153:25-34.

Mumby PJ, Harborne AR. Marine reserves enhance the recovery of corals on Caribbean reefs. PloS ONE. 2010; 5:e8657. [PubMed: 20066158]

Mumby PJ, Dahlgren CP, Harborne AR, Kappel CV, Micheli F, Brumbaugh DR, Holmes KE, Mendes JM, Broad K, Sanchirico JN, Buch K, Box S, Stoffle RW, Gill AB. Fishing, trophic cascades, and the process of grazing on coral reefs. Science. 2006; 311:98-101. [PubMed: 16400152]

Mumby PJ, Harborne AR, Williams J, Cappel CV, Brumbaugh DR, Micheli F, Holmes KE, Dahlgren CP, Paris CB, Blackwell PG. Trophic cascade facilitates coral recruitment in a marine reserve. Proc Natl Acad Sci. 2007; 104:8362-8367. [PubMed: 17488824]

Pauly D. Anecdotes and the shifting baseline syndrome of fisheries. Trends Ecol Evolut. 1995; 10:430.

Price ARG. Echinoderms of Saudi Arabia. Comparison between echinoderm faunas of Arabian Gulf, SE Arabia, Red Sea and Gulfs of Aqaba and Suez. Fauna of Saudi Arabia. 1982; 4:3-21.

Price ARG. Simultaneous 'hotspots' and 'coldspots' of marine biodiversity and implications for global conservation. Mar Ecol Prog Ser. 2002; 24:23-27.

Purkis SJ, Riegl B. Spatial and temporal dynamics of Arabian Gulf coral assemblages quantified from remote-sensing and in situ monitoring data. Mar Ecol Prog Ser. 2005; 287:99-113.

Purkis SJ, Riegl B, Andréfouët S. Remote sensing of geomorphology and facies patterns on a modern carbonate ramp (Arabian Gulf, Dubai, UAE). J Sediment Res. 2005; 75:861-876.

Purkis S, Renegar DA, Riegl B. The most temperature-adapted corals have an Achilles' heel. Mar Pollut Bull. 2011; 62:246-250. [PubMed: 21094502]

Richlen ML, Morton SL, Jamali EA, Rajan A, Anderson DM. The catastrophic 2008-2009 red tide in the Arabian Gulf region, with observations on the identification and phylogeny of the fish-killing dinoflagellate Cochlodinium polykrikoides. Harmful Algae. 2010; 9:163-172.

Riegl B. Inhibition of reef framework by frequent disturbance: examples from the Arabian Gulf, South Africa, and the Cayman Islands. Palaeogeogr Palaeoclimatol Palaeoecol. 2001; 175:79-101.

Riegl B. Effects of the 1996 and 1998 positive sea-surface temperature anomalies on corals, coral diseases and fish in the Arabian Gulf (Dubai, UAE). Mar Biol. 2002; 140:29-40.

Riegl B. Global climate change and coral reefs: different effects in two high latitude areas (Arabian Gulf, South Africa). Coral Reefs. 2003; 22:433-446. 
Riegl B, Purkis SJ. Detection of shallow subtidal corals from IKONOS satellite and QTC View (50, $200 \mathrm{kHz}$ ) single-beam sonar data (Arabian Gulf; Dubai, UAE). Remote Sens Environ. 2005; 95:96-114.

Riegl B, Purkis S. Model of coral population response to accelerated bleaching and mass mortality in a changing climate. Ecol Modell. 2009; 220:192-208.

Riegl, BM.; Purkis, SJ., editors. Coral Reefs of the Gulf: Adaptation to Climatic Extremes. Springer; 2012. p. 389hard cover

Riegl BM, Purkis SJ, Al-Cibahy AS, Abdel-Moati MA, Hoegh-Guldberg O. Present limits to heatadaptability in corals and population-level responses to climate extremes. PLoS One. 2011; 6:e24802. [PubMed: 21949755]

Riegl, BM.; Benzoni, F.; Samimi-Namin, K.; Sheppard, C. The Hermatypic Scleractinian (Hard) Coral Fauna of the Gulf. In: Riegl, BM.; Purkis, SJ., editors. Coral Reefs of the Gulf: Adaptation to Climatic Extremes. Springer; Netherlands: 2012. p. 187-224.

Sale PF, Cowen RK, Danilowicz BS, Jones GP, Kritzer JP, Lindeman KC, Planes S, Polunin NVC, Russ GR, Sadovy YJ, Steneck RS. Critical science gaps impede use of no-take fishery reserves. Trends Ecol Evolut. 2005; 20:74-80.

Sale PF, Feary DA, Burt JA, Bauman A, Cavalcante G, Drouillard K, Kjerfve B, Marquis E, Trick C, Usseglio $\mathrm{P}$, van Lavieren $\mathrm{H}$. The growing need for sustainable ecological management of marine communities of the Gulf. Ambio. 2011; 40:4-17. [PubMed: 21404819]

Samimi-Namin K, van Ofwegen LP. Some shallow water octocorals (Coelenterata: Anthozoa) of the Persian Gulf. Zootaxa. 2009; 2058:1-52.

Samimi-Namin K, Risk MJ, Hoeksema BW, Zohari Z, Rezai H. Coral mortality and serpulid infestations associated with red tide, in the Gulf. Coral Reefs. 2010; 29:509.

Samimi-Namin, K.; van Ofwegen, LP. The Octocoral Fauna of the Gulf. In: Riegl, BM.; Purkis, S., editors. Coral Reefs of the Gulf: Adaptation to Climatic Extremes. Springer; Netherlands: 2012. p. 225-252.

Shallard B, Associates. Distribution and abundance of small pelagic resources in UAE Waters. Technical Report 2. Fish Resource Assessment Survey Project of Abu Dhabi and UAE Waters. Bruce Shallard and Associates and Government of Abu Dhabi. 2003:101.

Sheppard C, Loughland R. Coral mortality and recovery in response to increasing temperature in the southern Arabian Gulf. Aquat Ecosyst Health Manage. 2002; 5:395-402.

Sheppard, C.; Price, A.; Roberts, C. Marine Ecology of the Arabian Region: Patterns and Processes in Extreme Tropical Environments. Academic Press; London: 1992.

Sheppard, CRC.; Wilson, SC.; Salm, RV.; Dixon, D. Reefs and Coral Communities of the Arabian Gulf and Arabian Sea. In: Mc Clanahan, T.; Sheppard, CRC.; Obura, D., editors. Coral Reefs of the Western Indian Ocean: Ecology and Conservation. Oxfoard University Press; 2000.

Sheppard C, Al-Husiani M, Al-Jamali F, Al-Yamani F, Baldwin R, Bishop J, Benzoni F, Dutrieux E, Dulvy NK, Durvasula SRV, Jones DA, Loughland R, Medio D, Nithyanandan M, Pilling GM, Polikarpov I, Price ARG, Purkis S, Riegl B, Saburova M, Namin KS, Taylor O, Wilson S, Zainal K. The Gulf: a young sea in decline. Mar Pollut Bull. 2010; 60:13-38. [PubMed: 20005533]

Sheppard, C.; Al-Husiani, M.; Al-Jamali, F.; Al-Yamani, F.; Baldwin, R.; Bishop, J.; Benzoni, F.; Dutrieux, E.; Dulvy, NK.; Durvasula, SRV.; Jones, DA.; Loughland, R.; Medio, D.; Nithyanandan, M.; Pilling, GM.; Polikarpov, I.; Price, ARG.; Purkis, SJ.; Riegl, BM.; Saburova, M.; Samimi-Namin, K.; Taylor, O.; Wilson, S.; Zainal, K. Environmental concerns for the future of Gulf coral reefs. In: Riegl, BM.; Purkis, S., editors. Coral Reefs of the Gulf: Adaptation to Climatic Extremes. Springer; Netherlands: 2012. p. 349-373.

Shojae F, Kamrani E, Shokri MR, Ranjbar MS, Moradi M, Hesni MA. New records of three hard coral species from north-east of Larak Island (Gulf, Iran). Mar Biodivers Rec. 2010; 3:e65.

Sutherland WJ, Adams WM, Aronson RB, Aveling R, Blackburn TM, Broad S, Ceballos G, Cote IM, Cowling RM, Fonseca GAB, Dinerstein E, Ferraro PJ, Fleishman E, Gascon C, Hunter M Jr, Hutton J, Kareiva P, Kuria A, MacDonald DW, MacKinnon K, Madgwick FJ, Mascia MB, McNeely J, Milner-Gulland EJ, Moon S, Morley CG, Nelson S, Osborn D, Pai M, Parsons ECM, Peck LS, Possingham H, Prior SV, Pullin AS, Rands MRW, Ranganathan J, Redford KH, Rodriquez JP, Seymour F, Sobel J, Sodhi NS, Stott A, Vance-Borland K, Watkinson AR. One 
hundred questions of importance to the conservation of global biological diversity. Conserv Biol. 2009; 23:557-567. [PubMed: 19438873]

Swift SA, Bower AS. Formation and circulation of dense water in the Persian/Arabian Gulf. J Geophys Res. 2003; 108:3004.

Tuya F, Boyra A, Sanchez-Jerez P, Haroun R. Non-metric multivariate analysis of the demersal ichthyofauna along soft bottoms of the Eastern Atlantic: comparison between unvegetated substrates, seagrass meadows and sandy bottoms under the influence of seacage fish farms. Mar Biol. 2005; 147:1229-1237.

Vajed Samiei, J.; Dab, K.; Ghezellou, P.; Shirvani, A. Some Scleractinian Corals (Scleractinia: Anthozoa) of Larak Island. Persian Gulf: Zootaxa; in press

Van Lavieren, H.; Burt, J.; Feary, DA.; Cavalcante, G.; Marquis, E.; Benedetti, L.; Trick, C.; Kjerfve, B.; Sale, PF. Managing the Growing Impacts of Development on Fragile Coastal and Marine Ecosystems: Lessons from the Gulf. A Policy Report. UNU-INWEH; Hamilton, ON, Canada: 2011.

Wiedenmann, J.; D’Angelo, C.; Smith, EG.; Hunt, AN.; Legiret, FE.; Postle, AD.; Achterberg, EP. Nutrient enrichment can increase the susceptibility of reef corals to bleaching. Nature Climate Change. 2012. http://dx.doi.org/10.1038/nclimate1661

Wilkinson, C., editor. Status of Coral Reefs of the World: 2008. Global Coral Reef Monitoring Network and Reef and Rainforest Research Center; Townsville, Australia: 2008. p. 296

Wilson SK, Adjeroud M, Bellwood DR, Berumen ML, Booth D, Bozec Y, Chabanet P, Cheal A, Cinner J, Depczynski M, Feary DA, Gagliano M, Graham NAJ, Halford AR, Halpern BS, Harborne AR, Hoey AS, Holbrook S, Jones GP, Kulbiki M, Letourneur Y, De Loma TL, McClanahan T, McCormick MI, Meekan MG, Mumby PJ, Munday PL, Öhman MC, Pratchett MS, Riegl B, Sano M, Schmitt RJ, Syms C. Critical knowledge gaps in current understanding of climate change impacts on coral reef fishes. J Exp Biol. 2010; 213:894-900. [PubMed: 20190114] 


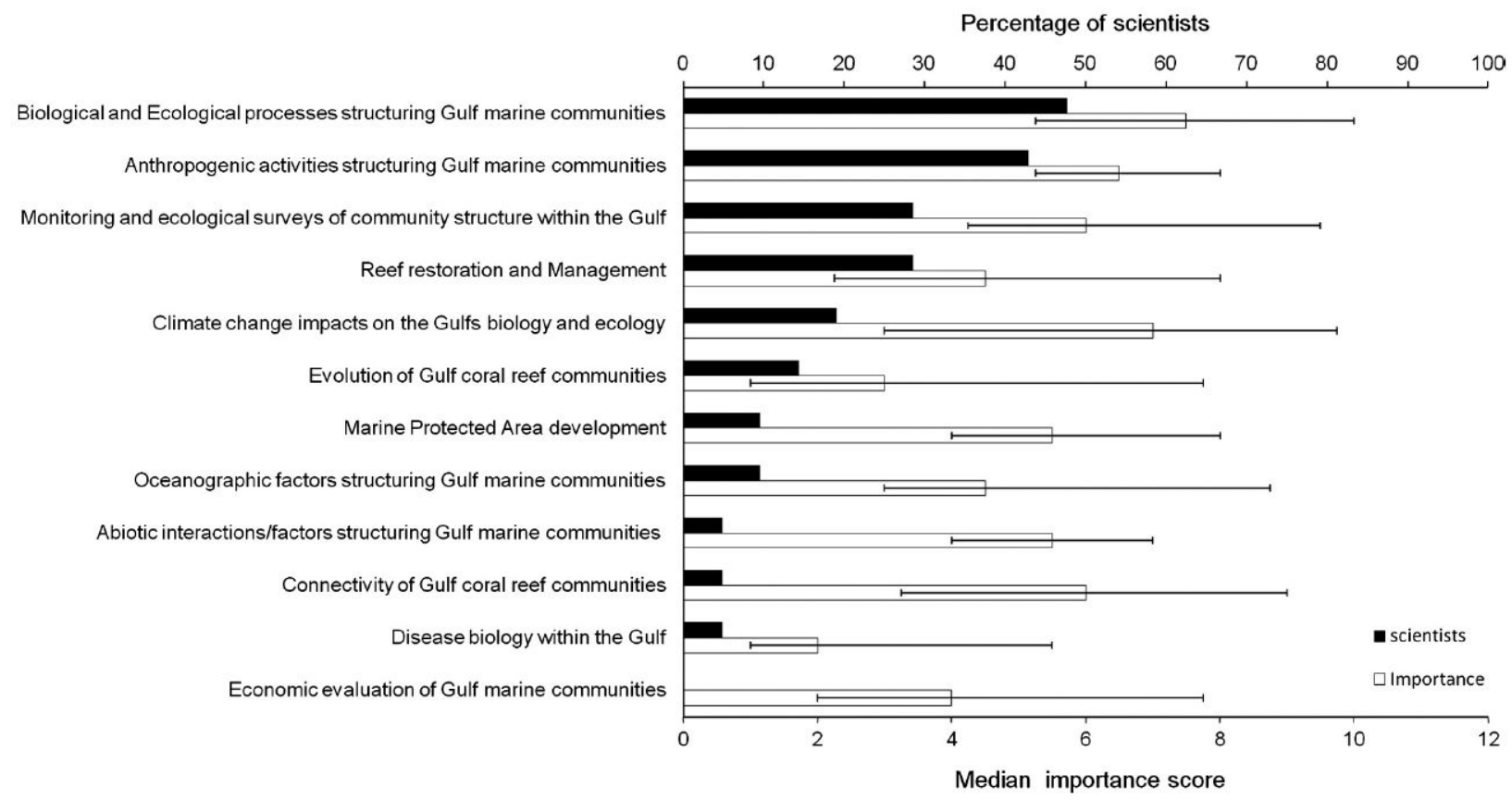

Fig. 1.

Research areas of scientists and median importance scores given to these research areas in the Gulf. Error bars represent the 25th and 75th percentile of data. 


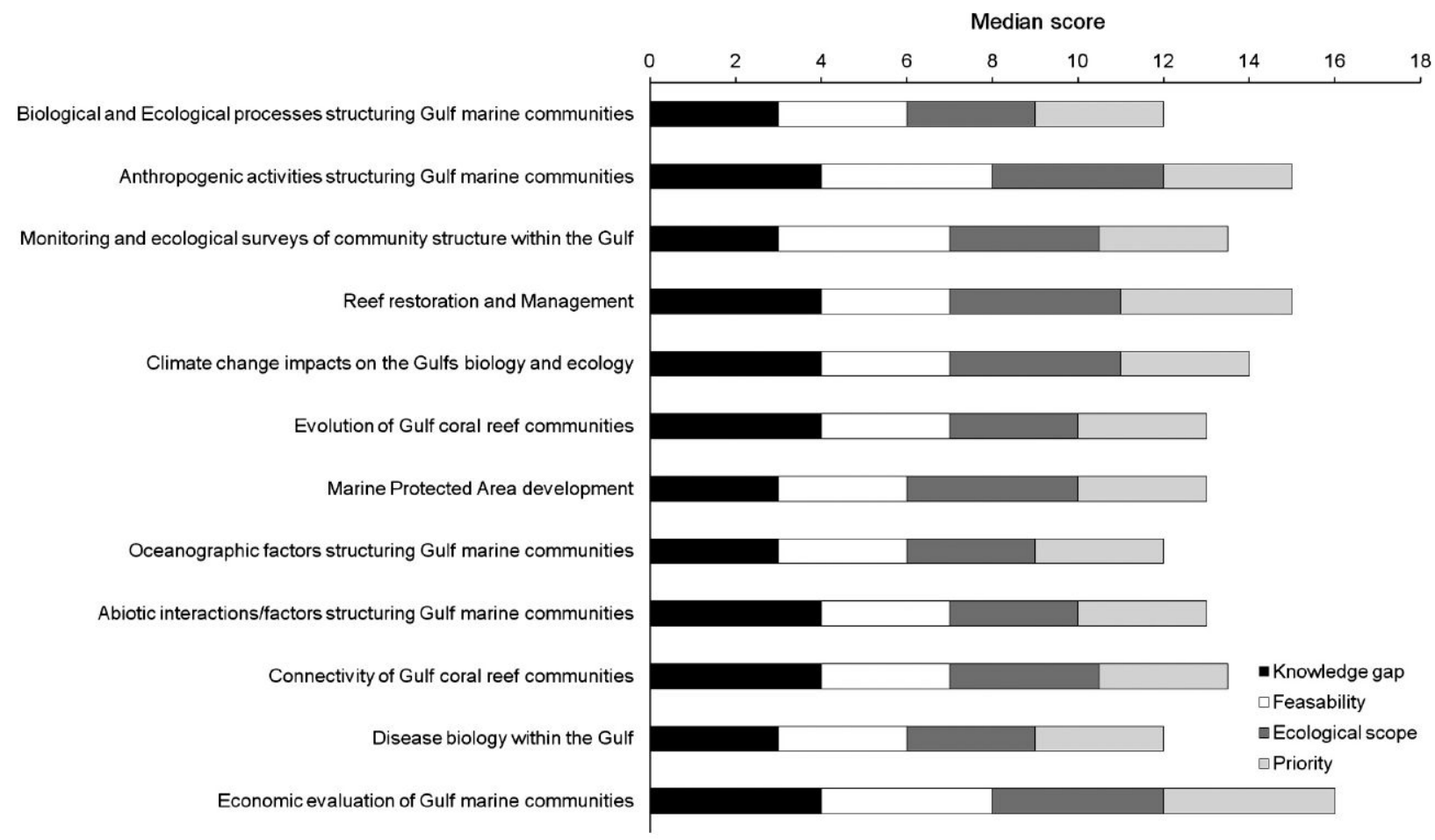

Fig. 2.

Median scores given to proposed research questions in four evaluation attributes. 


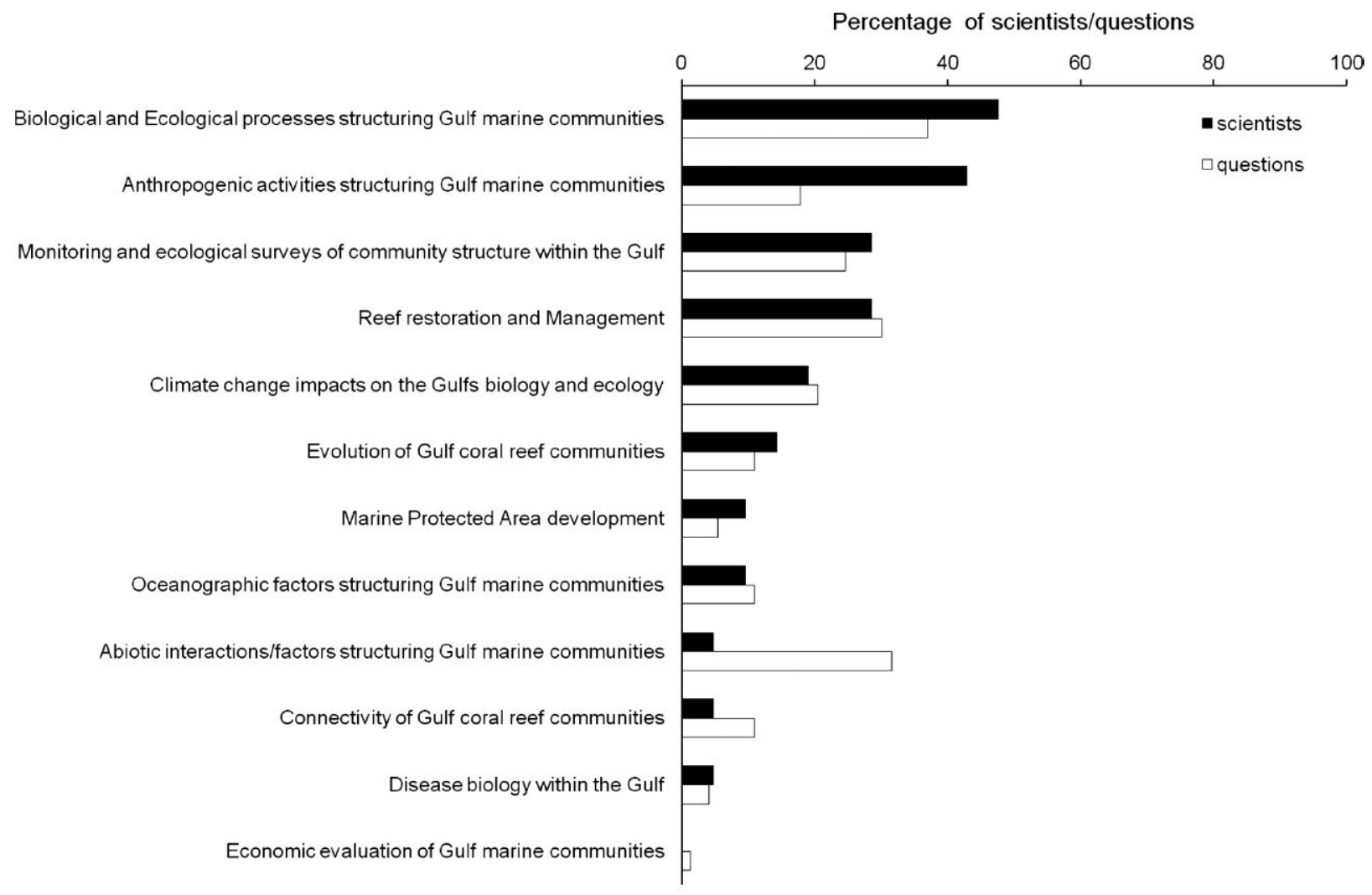

Fig. 3.

Research areas of scientists and areas of 71 research questions proposed for the Gulf. 